\title{
Tonalidades afetivas fundamentais e o deslocamento do humano em Heidegger
}

\section{Fundamental affective tones and the displacement of the human in Heidegger}

\author{
Dndo. Rodrigo Amorim Castelo Branco \\ rodrigocasbranco@gmail.com \\ Universidade de Brasília (UnB)
}

\section{RESUMO}

A partir do pensar do outro princípio em Heidegger, a tentativa deste texto é instaurar uma relação entre tonalidades afetivas (Stimmungen) e o deslocamento do humano da zona do ente à dimensão do seer. Para tanto, refletimos sobre a transição ontológica que retira o sujeito do mundo das representações técnicas e o insere na dimensão da verdade originária, a fim de demonstrar a sua real condição existencial na qual sempre está situado: condição de finitude. As meditações fenomenológicas de Heidegger revelam a situação indigente na qual todo e qualquer ente está. Indigência, contrária a qualquer juízo negativo, significa o reconhecimento do Da-sein (o ente deslocado) de que a sua existência é fundamentada pelo acontecimento abissal do seer. Por outro lado, o esquecimento dessa verdade lança o sujeito na ausência de indigência, isto é, na falta de consciência de pobreza e finitude, uma vez que se autodeclara fundamento de si mesmo. Nesse sentido, podemos dizer que tal esquecimento é o que caracteriza o pensamento do primeiro princípio no Ocidente.

\begin{abstract}
From the thinking of the other principle in Heidegger, the attempt of this text is to establish a relationship between affective tones (Stimmungen) and the displacement of the human from "being" to the dimension of beyng. Therefore, we reflect on the ontological transition that removes the subject from the technical representations world and inserts it into the dimension of the originating truth, in order to demonstrate its real existential condition in which the subject is always situated: a finitude condition. Heidegger's phenomenological meditations reveal the indigent situation in which all and any being stands. Indigence, contrary to any negative judgment, means the recognition of Da-sein (the displaced being) that its existence is based on the abyssal event of the beyng. On the other hand, the forgetfulness of this truth throws the subject in the absence of indigence; this is, in the lack of awareness of poverty and finitude, since it declares itself its own foundation. In this sense, we can say that such forgetfulness is what characterizes the thought of the first principle in the Occident.
\end{abstract}

Palavras-chave: Indigência. Princípio. Seer. Da-sein. Tonalidades afetivas.

Keywords: Indigence. Principle. Beyng. Da-sein. Affective tones. 


\section{Introdução}

As tonalidades afetivas tratadas neste texto são retenção (Verhaltenheit), pudor (Scheu), pressentimento (Ahnung) e espanto na forma de assombro entre os gregos (Erstaunen), mas enquanto temor (Erschrecken) em Heidegger, levando em conta o modo como essas tonalidades deslocam o humano das representações usuais cotidianas e o tornam um acolhedor do seer/Seyn1. A obra do filósofo que mais colabora para o desenvolvimento deste artigo são as Contribuições à filosofia (Do acontecimento apropriador), tradução do texto original Beiträge zur Philosophie (Vom Ereignis), 19361938, GA 65, publicação póstuma de 1989. As referidas tonalidades afetivas e o deslocamento do humano são discutidos a partir das meditações que Heidegger faz acerca do primeiro princípio (der erste Anfang) e do outro princípio (der andere Anfang) no pensamento ocidental, buscando refletir de que modo as tonalidades situam o ser (existência) do Da-sein em ambos e distintos princípios.

O que são e o que compreendem os dois princípios? O primeiro se dá no Ocidente a partir do pensar grego, desde os filósofos da natureza2 até a era coeva, tempos estes que Heidegger chama de a era nuclear na obra Serenidade [Gelassenheit, 1944-1945, GA 13]. O primeiro princípio, com o advento do pensar platônico, torna-se metafísico, modulador, isto é, representativo a ponto de identificar ser com o ente. Aqui ingressa o pensamento das Contribuições, que não busca definir o seer, mas o acolhe em sua profunda constrição, em seu mais simples velamento, característica esta fundamental do outro princípio do pensamento.

Seer, com escrita distinta da usual, é a tradução portuguesa do fundamento ontológico chamado Seyn por Heidegger. No idioma inglês, do mesmo modo, substituise o " $\mathrm{i}$ ” de being, permitindo uma forma de grafia neológica: beyng. Mas, cabe a pergunta: por que Heidegger escreve Seyn com “y”, deixando a palavra estranha ao modo corrente como a vemos nos livros filosóficos que tratam de questões metafísicas? O pensador assim o faz para demonstrar que o seer do qual ele "trata" é a essência em sua total diferença ontológica em relação às modulações da metafísica, que secularmente

\footnotetext{
1 Nas Contribuições à Filosofia (Do acontecimento apropriador), publicadas pela editora Via Verita em 2015, Marco Antônio Casanova traduz o termo alemão Seyn por seer. Quando escrevo "ser" em sua forma usual, refiro-me a essa essência ontológica ligada ao primeiro princípio do pensar.

2 Comumente chamado de filósofos pré-socráticos.
} 
esqueceram o caráter velado do ser. A partir dessas informações prévias, o leitor, no decorrer de sua visita a este texto, pode compreender como as tonalidades afetivas pertencentes ao outro princípio fazem do Da-sein um lançamento deslocado da objetividade do mundo técnico, aberto às veredas indizíveis do seer. Essa metamorfose indica que o humano que se permite estar no mundo como Da-sein se pauta no cuidado (Sorge) e no pudor (Scheu) para se tornar o custódio da verdade originária (Seyn). No entanto, essa verdade é abismal, pois revela que ser-aí é possibilidade, mas também é indigente no mundo. O que isso significa? Indica que o seer, fundamento originário, bate em retirada, velando-se para todo ente e deixando o Da-sein responsável por sua ipseidade.

\title{
1. Tonalidades afetivas fundamentais (Grundstimmungen)
}

Tonalidade afetiva (Stimm-ung) é chamada por Inwood de humor básico. Outros estudiosos de Heidegger a chamam de entoação, afinação ou disposição. A palavra alemã Stimm-ung deriva de Stimme (voz), aquilo que possibilita afinar (stimmen), por exemplo, um piano ou um violino. No campo da musicalização, Stimme permite a afinação do instrumento a partir do ressoar de sua "voz" (sonoridade). Stimm-ung como en-toação traz o tom estrutural que afina o Da-sein à senda do ser a cada época. Segundo Casanova:

\begin{abstract}
O termo alemão Stimmung possui um campo semântico deveras peculiar. Traduzido em sua dimensão mais coloquial, o termo indica um 'estado de humor', um 'afeto', uma 'disposição', assim como uma 'atmosfera' que se forma em um ambiente ou um 'astral' que surge em determinada circunstância. $\mathrm{O}$ uso heideggeriano do termo, por sua vez, procura retirar da palavra toda e qualquer conotação subjetivista. Para Heidegger, a Stimmung não é um estado de humor ou uma afecção do sujeito, mas aponta muito mais para a afinação de todos os elementos que tomam parte em uma situação, para uma harmonia do mundo enquanto abertura do ente na totalidade. Em sua relação com Stimme [voz] e stimmen [afinar], a Stimmung indica o estabelecimento de uma afinação harmônica. A essa significação acrescentamos o adjetivo 'afetivo' apenas porque a Stimmung se abate sobre nós como um afeto, como um páthos. $\mathrm{O}$ próprio Heidegger traduziu em seus escritos de juventude o termo grego páthos por Stimmung (CASANOVA, N. do T., n. ${ }^{\circ} 1$, p. 3).
\end{abstract}

Nas Contribuições à filosofia de Heidegger, a Stimm-ung de suas meditações demonstra que proposições conceituais e lógicas não representam, de modo algum, o originário. A filosofia heideggeriana permanece o mais estranha, pois se dá no outro princípio do pensar (andere Anfang), onde o temor (das Erschrecken) é a essência da meditação filosófica. O outro princípio do pensar indica o que se dá agora na 
contemporaneidade: uma filosofia que busca acolher o seer como a essência que, durante a história do Ocidente, esteve velado ao retirar-se do campo de representação do sujeito, abandonando-o de tempos em tempos. O outro princípio é o momento histórico que reconhece o seer em sua ocultação. É justo essa constrição do fundamento que se ausenta aos olhos do ente e o lança no mundo como projeto pobre e finito.

O primeiro princípio (der erste Anfang) se dá desde os gregos, sobretudo quando o aspecto platônico passa a subjugar o desvelamento da $\alpha \lambda \eta \dot{\vartheta} \varepsilon ı / a l e ́ t h e i a$. Trata-se de uma vontade metafísica de verdade e de correção que perpassa a história do pensamento antigo até o contemporâneo. A tonalidade afetiva do primeiro princípio que se torna o motor do pensar helênico é o espanto como $\theta \alpha u \mu \alpha ́ \zeta \zeta / t h a u m a d z o$, isto é, o filosofar a partir da admiração no âmbito do assombro, do estupor (Erstaunen), desse maravilhamento do ente em associação ao ser. Todavia, no outro princípio acenado por Heidegger, a tonalidade afetiva fundamental (Grundstimmung) é o espanto (das

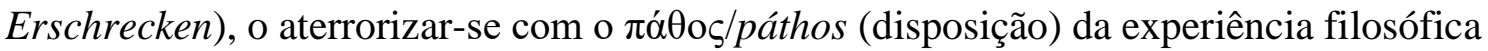
hodierna que parte do abandono do seer. Ou seja, o espantar-se no sentido de Erschrecken indica não o espanto por admiração (experiência grega), mas se trata da perplexidade do terror perante o nada, o vazio, a nulidade do seer/Seyn.

[...] o humor básico dominante passa a variar historicamente. O humor básico
do "primeiro começo" era o "espanto", enquanto o "humor básico do
pensamento no outro começo vibra nos humores que podem ser chamados" de:
pavor (Erschrecken), moderação (Verhaltenheit) - estes juntos são
pressentimentos (Anhung) e timidez (Scheu) (INWOOD, 2002, p. 8).

O filosofar do outro princípio emerge do espanto enquanto terror. "O espantar-se deixa que o homem volte para o fato de que o ente é e de que esse - o seer - abandonou todo "ente" (HEIDEGGER, 2015, p. 19). Nada mais espantoso do que pensar que o fundamento nos abandonou. No entanto, esse espanto não significa retrocesso ao perceber que seer é recusa, porque, na verdade, sua denegação prontifica o ente humano à vigência e doação ontológicas. É assim que seer ecoa. Nessa retenção (Verhaltenheit), compreende-se que seer se dá como privação hesitante em sua essenciação (vigência). Isto é, ele se essencia no constante velamento quando vem à tona, na iluminação retraída, na manifestação-ocultante de seu desvelar-se velado. Perante o abandono do seer, o $D a$ sein retém essa verdade com pudor e moderação.

A retenção (Verhaltenheit) indica reter-se, conter-se, deter-se; contenção, continência, moderação, reticência. Esse é o estilo do pensar heideggeriano que aponta 
para outro caminho meditativo estranho às predicações e cálculos com os quais o Ocidente está acostumado a lidar. Trata-se de uma tonalidade afetiva que começa a mudar a postura filosófica corrente, já que se afina à essenciação do seer e suporta a fundação do acontecimento apropriador (Ereignis). Aqui a vigência do seer convoca o ente a partir de seu retraimento. Esse estilo de filosofar, ao invés de estar à procura da entidade do ente, da presença fundante, coloca esse percurso do pensar ocidental em suspeita. O que Heidegger busca, nas Contribuições, é se dirigir ao caminho que perscruta sobre o modo essencialmente negativo3 do seer se dar. Assim, a retenção "é a atitude própria do pensar: um retraimento que exige, em vez de ação, a calma; em vez da palavra incontida e do discurso inflamado, o silêncio e a meditação; em vez da participação e da intervenção imediatas, a suspeita sobre o seu alcance e os seus efeitos" (SÁ, 2003, pp. 43-44, grifos do autor). É esse modo de pensar que simboliza a serenidade (Gelassenheit) capaz de sustentar os acenos e a recusa que se prenunciam no outro princípio da história ocidental.

O Da-sein, deslocado do mundo ôntico, torna-se o acolhedor das re-velações que se deram, que se dão e que se darão durante a história. O acolhimento que Heidegger cita nas Contribuições acontece como insistência (Inständigkeit) do Da-sein na guarda daquilo que não se identifica com o ente. A partir dessa tonalidade afetiva, ele se dedica a ser partícipe da diferença ontológica que se apresenta no acontecimento apropriador. Contudo, que distinção aparece nesse evento que se acena e toca a humanidade do humano? Na abertura do fundamento, a cisão entre seer e ente se apresenta, possibilitando a transição para o outro princípio, uma vez que o lugar de origem do seer é verdadeiramente compreendido como fundamento nulo que convoca o Da-sein a ser guardião de tal nulidade. Aqui há ligação seer-ente, mas ela não elimina a cisão ontológica entre ambas as dimensões. Nesse sentido, insistência significa:

\begin{abstract}
deter-se na diferença e nela longamente (de)morar [...]; estar próximo e intimamente situado dentro do acontecimento da diferença. Nessa direção, a experiência necessária é aquela de suportar a sua abertura, o seu $D a$, até que se faça plenamente distinta a cisão entre ser e ente, resolvendo o conflito do aparecimento do mundo histórico e do velamento do ser. Por isso, a insistência remete à ousadia e ao esforço de realizar e consumar determinada diferença entre ser e ente (RAMOS, 2015, pp. 254-255).
\end{abstract}

3 Não se trata de uma concepção pejorativa acerca do seer. O termo "negativo" visa demonstrar que o mistério essenciante está no seu constante advento como ausência fundante. 
O esforço da insistência realiza a diferença (Unterschied). Acolhe-se o fundamento que se doa ao modo de recusa. Seer é doação na medida em que se desvela como não-ente, como essencialidade (Wesenheit). Essa é a forma como o Da-sein o retém. A retenção (Verhaltenheit) é o meio para o espanto (Erschrecken), é a experimentação do abandono do seer por parte do humano, já que no outro princípio do pensamento, seer não é entidade regente da totalidade, não é absoluto, não é consciência ou uma forma maior e suprema de representação. Na verdade, o fundamento deixa de ser e se converte em nãoser, isto é, torna-se um vazio que muito expressa e doa possibilidades. O nada que a vigência do seer traz em sua apropriação não é um deserto, não advém para gerar desordem, descaminhos ou ausência de sentido à facticidade humana. Ao contrário, a nadificação permitida pela essenciação ontológica sacode o mundo do Da-sein a ponto de erguê-lo como o ambiente das oportunidades para se criar, viver, produzir, experienciar, enfim, para que o ente humano se projete e se factize a partir das condições que lhe são concebidas na existência.

A factização do Da-sein acontece, entre tantas outras tonalidades afetivas, graças ao temor quando se tem a consciência de estar em meio ao fundamento ausente, que revela a silenciosa voz do seer (Stimme des Seyns) ressoando no ente. Trata-se da tonalidade afetiva do pudor (Scheu) que acolhe, com decoro, a en-toação, o apelo do mistério. Segundo Heidegger, o pudor, assim entendido, não pode ser pensado usualmente como timidez. Essa tonalidade afetiva indica silenciamento e reverência perante o essenciar-se hesitante do seer como acontecimento apropriador. Essa en-toação é o modo do Da-sein estar afinado com aquilo que nele soa e ressoa e que permite que o fundamento a ele se doe. "O pudor é o modo do aproximar-se e do permanecer perto do que há de mais distante enquanto tal [...] que, contudo, em seu aceno - quando mantido no pudor - transforma-se no que há de mais próximo e reúne todas as referências do seer em si” (HEIDEGGER, 2015 , p. 20). É por meio dessa disposição ou páthos que o Da-sein se aproxima do mais longínquo, porque permite o aceno do seer, o seu ecoar no mundo. Surge uma afinação: a tonalidade afetiva da retenção atemorizada traz ao ente o pudor, afinando-o à abertura da simplicidade e à necessidade de abrigar, em si, a concessão do seer. Desse modo, ele se torna o cuidador, o guardião da verdade (der Wächter der Wahrheit). 
Ser guardião da verdade indica ter cuidado (Sorge)4, mas não enquanto pequena preocupação, ocupação com qualquer coisa objetiva no mundo ou com as aflições e apertos da vida cotidiana. Essas ocupações, sentimentos e vivências fácticas do Da-sein são modos de cuidado, mas sob a ótica da Besorgen.5 O cuidado (cura) essencial, no sentido aqui discursado, não pode ser compreendido a partir de leituras psicologizantes ou culturais. Ele não parte de uma postura da vontade, não se deixa calcular pelas faculdades volitivas e cognoscitivas do ente, já que advém da retenção como abertura para a contiguidade-longínqua e silenciosa da essenciação ontológica. Na verdade, aqui a proximidade só se dá com a distância desse essenciar-se, à medida em que se escuta, no cuidado com o seer, apenas o aceno vizinho-distante desse mistério apropriador.

Cuidado aqui não se refere a "algo", muito além disso, dirige-se à simplicidade e à profundidade do "não-algo". É sobre esse cuidado que Heidegger, em Sobre o humanismo [Über den Humanismus, 1946, GA 9], inquire: "Para onde se dirige 'a cura' senão no sentido de reconduzir o homem de volta à sua Essência?” (HEIDEGGER, 1967, p. 34). Eis aqui o estilo do filosofar heideggeriano sustentado na retenção (Verhaltenheit), modo esse de pensar não respaldado na zona do ente, mas na dimensão do Nada fundante. E se esse é o caminho do cuidado, o ente humano "terá de aprender, primeiro, a existir no inefável [...] Antes de falar, o homem terá que deixar-se apelar pelo Ser mesmo [...]

\footnotetext{
4 A Sorge à qual nos referimos indica o cuidado com aquilo que nos funda (Seyn). Besorgen se refere ao cuidado cotidiano com a diversidade dos entes objetuais. Fürsorge é o "cuidado, preocupação por" alguém. Trata-se do Da-sein em seu existencial ser-com (Mit-sein). No ser-com-o-outro, o Da-sein pode ter Fürsorge inautêntica (a substitutiva-dominadora/der einspringend-beherrschenden), um modo de cuidado dominante, que se coloca no lugar do outro e supera os seus obstáculos, retirando a autonomia e a liberdade da alteridade. A Fürsorge autêntica (a antecipativa-liberatória/der vorspringend-befreienden) devolve o cuidado ao outro, liberta-o à sua própria lida com o mundo, à sua cura independente. Aqui, deve-se atentar para não se fazer uma leitura penalizante da inautenticidade do cuidado. Em Heidegger, a Fürsorge inautêntica não é julgada como modo lastimável de ser, mas uma possibilidade, um modus de ser-no-mundo (in-der-Welt-sein), de ser-aí. Em relação ao modo de ser Mit-sein, o Da-sein não é ser-com apenas quando está na presença da alteridade. Apesar de não estar com outro concretamente, o ente humano é Mit-sein: "Também o ser-sozinho do Dasein é ser-com no mundo. Só em um e para um ser-com um outro pode faltar [...] De outra parte, o factual ser-sozinho não é, por sua vez, suprimido porque um segundo ou talvez dez exemplares desse ente humano fiquem 'ao meu lado"' (HEIDEGGER, 2012, p. 349, § 26, grifos do autor). Como se vê na indicação, o Da-sein só pode sentir falta do outro na medida em que o seu existencial é sercom. Por outro lado, estar em conjunto com diversos entes humanos em um mesmo local não assegura o estar próximo ao outro de forma essencial, por não haver familiaridade. Desse modo, a partir da estrutura existencial do Mit-sein, o Da-sein tem a possibilidade de estar próximo daquele que se ausenta fisicamente, mas, outrossim, pode estar distante daquele que vige como presença constante.

5 Besorgen possui três significados: “(a) 'obter, adquirir, prover' algo para si mesmo ou para outra pessoa; (b) 'tratar de, cuidar de, tomar conta de' algo; (c) especialmente com o particípio passado, besorgt, 'estar ansioso, perturbado, preocupado' com algo. O infinitivo substantivado é das Besorgen, 'ocupação' no sentido de 'ocupar-se de ou com' algo" (INWOOD, 2002, p. 26).
} 
Somente assim se restituirá à palavra a preciosidade de sua Essência e, ao homem, a habitação para morar na Verdade do Ser" (HEIDEGGER, 1967, pp. 33-34).

Habitar, no sentido que Heidegger busca expressar, gera uma simultaneidade copertencente entre ente e seer, na medida em que o ôntico (existentivo) só tem seu lugar a partir do plano ontológico (existencial). Isso significa que o ente só ex-iste porque nele mora a verdade principial. O seer apenas se dá quando há ente para o fundamento (de)morar. Porém, em que medida pode ocorrer o (de)morar do seer na humanidade? A partir do momento em que o humano se tornar guardião do que possibilita o seu sendo singular e histórico. Desse modo, ele pode "tornar-se fundador e o guardião da verdade do seer, ser o aí como o fundamento usado pela própria essência do seer” (HEIDEGGER, 2015, p. 20).

Tornar-se o guardião da verdade do seer (Wächter der Wahrheit des Seyns) significa que o Da-sein se converte em o "buscador" (Sucher) do silêncio. A "meta" desse "buscar" não é forçosa ou pragmática, direcionada à objetualidade do mundo técnico. A radicalidade da natureza heideggeriana de filosofar (retenção da verdade como recusa) está em demonstrar que a "meta" é única e singular. "Essa meta é a própria busca, a busca do seer. Ela acontece e é mesmo a mais profunda descoberta, quando o homem se torna aquele que vela pela verdade do seer, o guardião daquele silêncio e é decidido nessa direção" (HEIDEGGER, 2015, p. 21). O "buscador" do que apela originariamente, antes de se decidir por trilhar tal caminho, é decidido pelo caminho. O trilhar não está determinado, mas, pelo seer, está acenado. Isso significa que o Da-sein, precedentemente, foi apropriado em sua busca e, a partir disso, foi "buscado", acometido. Se em sua busca o "buscador" foi tocado pelo mistério fundamental, a voz silenciosa, fundadora dos entes, está guardada.

A guarda evidencia que há aquele que custodia a verdade elementar, o preservador ou o custódio (Wahrer). Ele faz crescer a denegação do seer. Com a abertura da verdade, o Da-sein vige, torna-se, dessa forma, o lugar, o aí ( $D a$ ) da clareira (Lichtung). A clareira ressoa em todo ente, circunda tudo o que é, não apenas o humano. A humanidade está no âmbito ôntico que insiste e se sustenta nessa clareira (Seyn). Essa reserva fundamental de espaço que permite ao Da-sein se tornar o sítio da vigência ontológica é o que o faz ser ex-sistente, insistente na verdade ex-tática do seer. Aqui Da-sein não é um sujeito. Vige como humano, dispondo-se a ser morada do que se ausenta, habitando essa ausência. Por 
isso, diz Heidegger (1967, p. 46): "Enquanto ec-sistente, o homem suporta o Da-sein, assumindo, na 'cura', o lugar $(D a)$, como a clareira do Ser". Como preservador do seer, Da-sein cuida do que o torna aí $(D a)$ a cada instante, sendo a instância lançada no próprio lançamento originário. Os dispostos aos toques do nada mais se permitem o exercício do cuidado, esses raros e vindouros, não porque surgem como os melhores da humanidade, mas porque, cientes de sua indigência6, buscam abrigar o fundamento de sua finitude.

Nos parágrafos sobreditos, houve referência ao estilo de filosofar heideggeriano enquanto retenção (Verhaltenheit). O cuidado na retenção está em virtude da originariedade da abertura. "A retenção, o meio afinador do espantar-se e do pudor, o traço fundamental da tonalidade afetiva fundamental, nela afina-se o ser-aí com vista ao silêncio. De maneira criadora, nessa tonalidade afetiva fundamental do ser-aí, o homem torna-se o guardião desse silêncio" (HEIDEGGER, 2015, p. 21, grifos do autor). Aqui reside o cuidado do Da-sein que busca e que se torna guardião da verdade. Esse é o seu traço fundamental: o decoro com a alteridade atópica que se re-vela e que Heidegger chama de Seyn.

O que Heidegger suscita é um choque na filosofia do Ocidente, dando motivos para ela se espantar com o abissal do fundamento esquecido, este que esteve em retração. Além disso, conduz-nos à "meta" do pensar digno, da meditação autêntica. Como foi salientado, aqui devemos ter o cuidado necessário com o termo para não confundirmos "meta" em seu sentido ontológico com a vontade cultural de progresso, finalidade pragmática ou caráter corrente do ente. “A própria busca é a meta. E isto significa: 'metas' estão ainda por demais ligadas ao primeiro plano e sempre continuam se colocando diante do seer - e soterram o necessário" (HEIDEGGER, 2015, p. 22). Como se vê, não é uma meta qualquer, mas é a busca do próprio silêncio para se escutar os acenos do seer. A retenção, após o espantar-se, permite o pudor silente, momento no qual o seer mais diz e pronuncia a verdade ao seu modo. A essência do ente humano passa a ser entendida a partir do seu fundamento, isto é, como Da-sein, este que se encontra apropriado em meio ao acontecimento originário e se aprofunda na virada (Kehre) ao outro princípio do pensamento que deixa a nulidade ontológica irradiar.

6 Indigência aqui significa: o Da-sein reconhece que é deixado pelo seer e assume que a sua finitude e pobreza se originam desse "ir-embora" do fundamento. 
O empenho heideggeriano, nas Contribuições, como o próprio pensador pronuncia, para nós chega a ser por demais estranho porque não pressentimos a nulidade fundante, essa simplicidade tão próxima, mas, ao mesmo tempo, tão distante por causa da ausência de indigência7 (die Not der Notlosigkeit) presente no pensar do Ocidente, já que permanecemos fora do saber meditativo. A privação de indigência, na verdade, é a carência de reconhecimento da finita facticidade humana. A tentativa de burlar essa finitude representa o aperto que angustia o ente e o direciona à técnica e à maquinação (Machenschaft). O refúgio para os entes dos tempos hodiernos também está nas diversas vivências (Erlebnisse), nesse vitalismo que a tudo deseja possibilitar, enquanto a simplicidade do seer continua esquecida enquanto o humano não se percebe pobre no mundo. Ora, se tudo se refere à vida, a falta de indigência chega ao seu extremo, já que não mais se nota que o silêncio essenciante pode nos deixar em contato com o aberto. Aqui, encontramos o cúmulo da carência de indigência no ente, já que ele não se espanta com a sua condição fugaz e com o velamento da verdade. Desconhecedor de sua pobreza existencial, por consequência, não é acenado pelo pudor (Scheu) e não é levado a silenciar-se na escuta do fundamento.

Estamos na questão pensante acerca da verdade do seer. Esse instante não pode ser devidamente fixável, estabilizado e, de forma alguma, determinável pelo calendário metafísico. O tempo aqui não é a temporalidade ôntica, mas o tempo é do próprio acontecimento apropriador, sem qualquer domínio calculante do ente. É por isso que o deslocamento ou a transição do humano do campo ôntico em direção à vigência do seer não pode ser objetivada historiologicamente, "porque a 'história' historiológica pública passou já muito tempo ao largo dessa transição [...] Assim, fica reservado para esse instante um longo caráter de futuro" (HEIDEGGER, 2015, p. 24). Aqui habita o assombro, já que o fundamento é abissal, tendo em vista que ele é nulo como uma ausência fora do prumo calculante e que se dá quando decide acenar-se para o Da-sein.

No ser-aí e enquanto ser-aí acontece apropriadoramente para o seer, que ele mesmo revela como a recusa, como aquela região do aceno e da subtração do silêncio [...] O homem não consegue realizar nada para tanto e é quando a preparação da fundação do ser-aí lhe é entregue como tarefa que ele se encontra menos em condições de tal realização, de tal modo que essa tarefa determina,

\footnotetext{
7 A ausência de indigência se dá quando o sujeito se autodefine como fundamento de si e dos outros entes. Ele não reconhece que é fundamentado pelo acontecimento do seer. Mergulhado na técnica, nega o seer e se entrega à dimensão das representações ônticas. Nesse sentido, carece a ele [o ente técnico] o silêncio que possa acolher o essencial, porque lhe falta senso de finitude.
} 
inicialmente, uma vez mais a essência do homem (HEIDEGGER, 2015, p. 24, grifos do autor).

Como esclarece a indicação heideggeriana, o Da-sein (ser-aí) nada mais produz: é apropriado por uma verdade originária que ele mesmo assume como fundamento em recusa. O seer se subtrai aos "poderes" maquinais, mas ainda assim se acena ao ente humano, permitindo a este realizar e se situar no mundo como um ser ex-istente, lançado como projeto (Geworfenheit). Trata-se de um espanto fáctico, já que o fundamento não é absoluto e sim fosso abismal. Não é presença concreta no mundo, mas um não-ente.

As tonalidades afetivas retenção (Verhaltenheit), espanto (Erschrecken) e pudor (Scheu) foram discutidas durante o texto. Heidegger cita outra tonalidade igualmente fundamental: o pressentimento (Ahnung). Espanto e pudor são como tremor e temor. Temor aqui não sugere amedrontamento, mas indica deferência frente ao insólito. Acerca da retenção, ela indica a contenção neste tremor e temor, enquanto o pressentimento traz o caráter de relacionamento, o elo com o vindouro, com o porvir, uma disposição que sente a nulidade do abismo (Ab-grund) na pele. Uma en-toação (Stimm-ung) que se sintoniza a outro modo de pensar não mediado pelo mundo predicativo. O pressentir experiencia a abertura do des-encobrimento. Sob essa ótica, compreende-se que nem tudo é entitativo, mas algo essencial e necessário permanece extra ao determinismo lógicoracional do ente. O pressentir traz um poder de afinação entre Da-sein e Seyn. Essa tonalidade afetiva é fundamental, já que prepondera sobre o entorpecimento da mera opinião, do falatório e da publicidade. O pressentimento é principial (anfänglich) porque traz ao Da-sein outra situação, outro princípio, uma instância distinta do que até o momento ocorreu na investigação metafísica. O pensar do outro princípio, que parte da ontologia tradicional, mas que visa superá-la, por não estar consolidado e bem visualizado, traz um certo receio. No entanto, também promove o entusiasmo, já que afina o Da-sein ao seu arché (Seyn). "O pressentimento posiciona a in-sistência inicial no seraí. Ela é em si horror e entusiasmo ao mesmo tempo - contanto, sempre, que, enquanto tonalidade afetiva fundamental, ela defina e determine aqui de maneira afinadora o estremecimento do seer no ser-aí enquanto ser-aí” (HEIDEGGER, 2015, p. 26).

O entusiasmo é pronunciado por Heidegger como abdicação. Se o seer se dá como recusa e se essa retração vige na guarda do Da-sein, conservada como velamento, dessa forma, a prontidão para essa ausência fundamental só pode acontecer com 
abdicação, que aqui não indica o simples deixar de querer ou o mero deixar de lado. De outro modo, significa o "estar com seer" na medida em que o Da-sein se eleva do mundo dos entes para ser apropriado pelo insondável do pensar, ou seja, pelo aceno da recusa (doação do Seyn). Aqui se trata de de-cisão (Ent-scheidung), com grafia distinta, para demonstrar que não indica o simples escolher (auswählen) entre um ente e outro, mas anuncia a de-cisão para o interior do outro princípio que ainda não se consolidou e, por isso, não se descreve e não se instrui. "Nessa decisão, o aberto da transição é retido e fundado - o em-meio-ao abissal do entre em relação ao não-mais do primeiro início e de sua história e ao ainda-não do preenchimento do outro início" (HEIDEGGER, 2015, pp. 26-27). De-cisão (Ent-scheidung) é (de)cisão com um princípio e conjunção com a abertura originária do outro princípio.

A de-cisão parte das tonalidades afetivas fundamentais, entre elas, o pressentimento (Ahnung), a partir do qual a projeção da verdade do seer é essenciada como recusa no Da-sein. Aqui se dá essa abertura ao insondável que abre o silêncio liberto da "violência" do ente. Assim, Heidegger elucida que o que se essencia/vigora não é um mero vazio visível e presente ao cálculo, mas a vigência mesma do acontecimento apropriador, que se apropria do Da-sein no instante do acometimento fundamental.

\section{A necessidade de deslocamento do humano}

O deslocamento aqui anunciado se refere à ultrapassagem humana do mundo habitual, onde reina o plano ôntico para o ingresso na dimensão ontológica do seer em sua inteira radicalidade. A radicalidade do seer está em sua diferença com o ente, no seu des-emparelhamento com o sujeito e suas modulações. O Da-sein, ao se despir da vontade de poder (der Wille zur Macht), é levado para fora do caminho estável no ente no qual há o domínio das representações. Mas surge a questão: há a possibilidade desse deslocamento efetivamente acontecer? A resposta de Heidegger é positiva. É possível graças àquilo que faz do humano um ser finito: a sua indigência advinda do abandono ontológico a partir do qual a essência originária se vela. Com base nisso, ao ente é permitido se juntar às distintas e variadas maquinações ou pode de-cidir pelo que é essencial. A indigência (reconhecimento de que o humano é fundado por uma alteridade nula chamada Seyn) aqui se torna o elemento auxiliar para que o Da-sein se desloque da 
cotidianidade média, do mundo impessoal, do se (das Man). Mas, e se o sujeito se estagnar na ausência de indigência que desconhece o seer como fundamento? Dessa forma, para Heidegger (2015, p. 30, grifo do autor), faz-se mister surgirem os raros e aptos, "porque eles sabem que padecem da indigência".

Indigência traz à tona a elevação espiritual daquele que se vê apropriado e fundado por uma verdade que se subtrai ao domínio da vontade. O Da-sein sereno se percebe indigente, pobre e finito, pois tem consciência de que é deixado pela partida daquilo que o funda a cada vez. $\mathrm{O}$ despertar à carência já é um incipiente deslocamento ao aberto. $\mathrm{O}$ Da-sein, ao se descobrir pobre de fundamento, abre-se ao seer. Essa radical transformação o faz guardião do aberto, um apropriado em meio ao acontecimento (Seyn) que não vige a não ser como evento apropriador (Ereignis). Na ótica de Heidegger, se o humano, graças à raridade do deslocamento, chega a se afinar ao mistério essenciante, dessa forma ele está no caminho do salto para o outro princípio da história, porque atua serenamente e medita em agradecimento ao que o faz pensar. Aqui temos o ente transformado, de-cidido e cindido, mas vinculado ao que é principial.

Enquanto a entidade é insistente na zona das vivências do ente, Da-sein persevera na ausência que irradia possibilidades. O seer é o mais próximo e, justamente por causa dessa contiguidade, que a atividade técnica e vivencial passa ao largo dessa abertura. $\mathrm{O}$ que Heidegger indica é que o acontecimento apropriador (velamento do seer) é aquilo que permanece como mais estranho e espantoso, já que é abertura abismal, não calculável e ininteligível às determinações ônticas. Mas a felicidade das visões de mundo populares está em encontrar um meio para trazer as coisas à vista, empreendendo-se a perseguir uma utilidade para o todo. No outro princípio, diferentemente, o totalmente outro (ganz andere) é pensado no momento em que o humano de-cide pelo acontecimento originário. Trata-se de uma virada clareadora-encobridora ao mesmo tempo, já que o fundamento é um desvelar-se em velamento, uma visita em retirada.

A abertura do seer se dá no tempo-espaço, no $\mathrm{Da}$ do Da-sein, que é sítio instantâneo do acontecimento apropriador. Destarte, o ente se encontra no seer, nessa vigência que se doa tacitamente. "O seer (como acontecimento apropriador) precisa do ente, para que ele, o seer, se essencie" (HEIDEGGER, 2015, p. 34) e, por isso, ele se dá no tempo-espaço. Mas, por vezes, o ente se define como inteiramente autônomo frente ao 
seer, como se este fosse uma mera abstração representacional. Isso é sinal de ausência de indigência do pensar que cega a humanidade, já que ela pensa o seer como presentidade.

Heidegger não concebe a história a partir de feituras ônticas, mas sim como realização graças à vigência ontológica. No deslocamento, tanto do fundamento como do ente humano, a essenciação do seer não é mera presentidade, é a plena vigência do abismo (Ab-grund) como verdade fundante. A esse respeito, salienta Heidegger:

O acontecimento apropriador é a própria história originária [...] Nesse conceito originário de história, conquista-se, pela primeira vez, o âmbito no qual se mostra [...] como a história é 'mais' do que ação e vontade. Também o “destino" pertence à história e não esgota sua essência (HEIDEGGER, 2015, p. 36).

A história vai além das mundividências humanas, supera suas ações e volições já que, desde o seu primeiro princípio, é fundada pelo acontecimento apropriador. $\mathrm{O}$ fundamento aberto é o destino que permite ao ente ser si mesmo por meio dos envios do seer que, por mais que se essencie durante as várias épocas históricas, não queima a sua chama, a sua claridade, podendo "iluminar" o Da-sein enquanto este durar.

Da-sein é quem medita nesse pensar meditativo. A partir de uma inquietação ontológica-existencial, faz a pergunta quem sou e questiona o seu sendo. Abre-se ao aberto e pressente o fundamento nulo que o fundamenta. Este pressentidor e indagador, para Heidegger, é uma raridade em meio ao mundo da publicidade e do falatório, uma vez que pergunta pelo seer porque o pressente (ahnt das Seyns). Mais do que ação do Dasein, há re-velação do fundamento, uma vez que seer, a cada momento, vem como um fluxo apropriador àqueles que estão dispostos a insistir nesse fenômeno. A sua vigência precisa de "fundadores", isto é, o acontecimento que apropria pressupõe uma duração no ente, um si-mesmo (Selbstheit) no qual ele possa se dar. Por outro lado, ao ente humano, só é possível o seu si-mesmo a partir do momento em que se abre ao toque do seer e, alcançado por este acometimento, dispõe-se a perguntar (fragen) o que é o humano.

O toque do fundamento, o pressentimento do Nada estimula o ente a perguntar sobre o que o torna ex-istente a cada instante e o põe diante do si-próprio. Trata-se de uma experiência nadificadora que impossibilita qualquer objetivação ou representação do seer. Embora a essenciação fundamental se dê como Nada, é justamente por esse meio irrepresentável que o seer soa, ressoa e se doa, estrutura ipseidades e, por consequência, permite ao humano deslocado pensar propriamente sobre o seu quem. Trata-se da própria convocação insigne ao ente que vigora como projeto lançado. Abrir-se a isso é evocar a 
pergunta existencial quem sou em retorno ao chamado do pensamento. Ou seja, a "resposta" (“Antwort”) do Da-sein ao acometimento originário é o seu perguntar (fragen). Trata-se de um questionar não judicativo, uma vez que ele não é tematizado ou ajuizado, mas advém, propriamente, do mistério da verdade. É por isso que podemos dizer que pensar (denken) é agradecer (danken) a essa verdade e ao seu envio de possibilidades. A esse respeito, expõe Fernandes:

A entrega do ser ao homem, portanto, é destinação e isso perfaz a essência da história. Na destinação (Geschick) do ser está um presentear-se (sich schenken), o dar-se de si como dádiva. Pensar (denken) é, justamente, agradecer (danken) este presentear-se do ser. Ereignis significa, portanto, o recolhimento na unidade amorosa de ente, presença e ser (FERNANDES, 2011, p. 170).

Ao aguardar a doação do seer como dádiva, isto é, a sua denegação, a filosofia aparece, nas Contribuições, como um saber inútil. A princípio, essa visão filosófica nos espanta, já que ela tanto realizou durante a história. No entanto, o dito heideggeriano indica que essa inutilidade reside porque a filosofia está no sítio da meditação (Besinnung) e não no pragmatismo técnico. A meditação aqui representa o questionamento acerca do sentido da verdade elementar, o salto para o profundo de sua essência. Nesse caminhar, eis a pergunta: quando e como o ente passa a pertencer ao acontecimento apropriador? Quem pode fazer essa pergunta é o humano deslocado, o Da-sein com decoro e pudor face ao que o situa na existência. Ele pode "fundar" a verdade ao ser por ela fundado. "Por isso, a meditação - salto para o interior da verdade do seer - é necessariamente automeditação" (HEIDEGGER, 2015, p. 46). Meditação (Besinnung) se dá como pergunta pelo sentido, pela verdade do seer (Frage nach dem Sinn, Wahrheit des Seyns). É o pensamento do sentido a respeito do fundamento da história; o meditar que segue o sentido da verdade em seu retraimento. Dessa doação re-veladora advém a automeditação (Selbstbesinnug) na qual o ente humano é lançado no mistério da verdade, impelido a questionar sobre o seu quem, a posicionar-se perante a pergunta quem sou. Como vimos anteriormente, trata-se de um perguntar não judicativo, tendo em vista que o questionar surge como "resposta" em agradecimento à essenciação fundamental. Aqui, não há relação de permuta maquinal entre humano e o que o principia. Como esclarecem Moraes e Bignotto:

A atitude, a que Heidegger conclama, é antes uma postura de silenciosa meditação (Besinnung); Heidegger dá a ela o nome de Bereitschaft preparação, disposição. Trata-se daquele recolhimento que se põe, 
reverentemente, à escuta da voz e do chamamento do ser, fazendo do pensamento um cuidar (hegen) e um tratar (pflegen) dos modos pelos quais o ser se desvela e se subtrai na clareira da verdade (MORAES; BIGNOTTO, 2001, p. 60).

A filosofia meditativa do outro princípio não se edifica junto ao ente, insiste Heidegger. A filosofia é fugidia a ele, porque se junta ao abismal da verdade. Ela parte da indigência mais extrema do primeiro princípio. A indigência retida no Da-sein é o que o faz ir para além do ente. Isso é o que Heidegger chama de caráter de jogado do humano no insondável, que é o elemento impulsionador para ultrapassar a sua própria esfera ôntica em direção ao aberto. No entanto, fica esclarecido que a filosofia como meditação não afasta a indigência do ente, pelo contrário, a suporta e a tem como o fundamento da história. Mas por que a indigência fundamenta a história humana? Porque, por mais que as epocalidades deem lugar ao principial, isto é, abram-se ao aberto, sempre continuarão no aperto, na penúria, na premência, tendo em vista que de tempos em tempos são abandonadas pelo seer. E mesmo quando seer se essencia, o Da-sein não o domina, uma vez que o fundamento é eclosão em velamento, ileso ao cálculo definidor. Ou seja, o caráter indigente de projeto jogado e finito representa a própria e irremissível facticidade do Da-sein. A esse respeito, elucida Heidegger:

Aquela indigência é, contudo, diversa nos inícios e transições essenciais da história do homem. Nunca, porém, calculando externamente e de maneira míope, pode tomar a indigência como uma falha, como uma miséria ou coisas do gênero. Ela se encontra para além de toda valoração 'pessimista' ou 'otimista'. Sempre de acordo com a experiência inicial dessa indigência, ela é a tonalidade afetiva fundamental que afina para a necessidade (HEIDEGGER, 2015, p. 48).

A indigência (Not) compreende o sentido de estar-no-aperto, que em grego se diz $\theta \lambda \tilde{i} \psi ı /$ / thlypsis. No novo testamento da Bíblia Sagrada, em João 16.33, lê-se: "Neste mundo vocês terão aflições; contudo, tenham ânimo!". Vê-se que estar-no-aperto para a linguagem bíblica indica aflição, tribulação, devendo-se suportá-la com ânimo e paciência, porque é isso que pode dar a volta na indigência. A paciência indica a própria necessidade (Notwendigkeit) para resistir ao que nos aperta ou àquilo que nos atribula. A Notwendigkeit é a necessidade da viragem ao não-necessário, ao Nada fundante que, gerando liberdade (Freiheit) ao humano, o libera das representações, tirando-o da atribulação da vida cotidiana. Assim, presenteia-se a filosofia com uma nova tarefa, outra necessidade (Notwendigkeit), isto é, um outro apelo, que não advém como demanda do 
ente e nem mesmo como uma necessidade da ontologia tradicional para satisfazer-se propriamente. Nesse sentido, salienta Heidegger apud Courtine (2006, p. 31): "não é a necessidade de uma época, a necessidade de um século, mas a necessidade de dois milênios, da indigência que nos torna necessitados desde que o pensamento é "metafísico"”. É a própria indigência milenar da história do Ocidente como história metafísica que traz à tona a Notwendigkeit, isto é, a necessidade de liberdade (Freiheit), de dar a volta no que nos atribula (Not), superar a falta de consciência de nossa carência. Nesse trilhar, tornamo-nos livres para outra necessidade quando vem à luz que o fundamento não se instaura no sujeito, mas no não-ente.

A indigência não é entendida por Heidegger sob a ótica moralizante no sentido de queda ou erro humano. "É a indigência que faz o homem se abrir para o aberto, dirigir-se para o pensar meditativo que suporta e fundamenta essa indigência" (HEIDEGGER, 2015, p. 49). Ela é o elemento que impulsiona a de-cisão do Da-sein em romper com a supremacia do poder subjetivo. O que presenciamos hoje não é o ente no exercício de reconhecimento de sua indigência, mas a sua vontade de poder que aparece, na verdade, como impotência do pensar, já que a determinação técnica se torna total e unitária, perdendo espaço o pensar próprio. Isso se dá pelo fato de o mistério essencial não ser levado a termo. A culminância da técnica e das vivências como efetividades, limitando espaços e distanciando a meditação autêntica, torna-se o próprio poder "autêntico". Acontece, assim, a falta de força a um pensar profundo acerca da abertura originária da verdade. $\mathrm{O}$ questionamento e a simplicidade de uma meditação essencial se tornam ausentes. A avidez por resultados que possam trazer novas vivências e novos afazeres ao público passam a imperar.

Não obstante, pensar a essência da verdade não acolhe imediatismo e valorações, porque pensar é meditar, é transposição para o profundo interior do seer. A estranheza do fundamento não se deixa colocar no jogo das objetivações do ente e não pode se pautar no êxito dos efeitos "causados" pela maquinação. O pensar é meditação sobre o seer, por isso a filosofia é necessária, já que pensa o fundamento. Aqui se dá outro mirar totalmente diverso dos "olhares metafísicos" configurados pelo cálculo e pela definição do humano como animal rationale. No outro pensar, o ente não é definido, mas interpelado: "a conclamação ao homem como a conclamação que o determina para a história" 
(HEIDEGGER, 2015, p. 54). Ele é fundado historicamente por meio da fundação do $D a$ sein como o aberto para a apropriação.

Quem se sacrifica pela preparação do outro princípio do pensamento se encontra em um momento transitivo fundamental, resistente ao ente e insistente no seer. É por meio da meditação que necessariamente acontece o inédito viável, que está em preparo, porque o acontecimento apropriador possui uma clareira para si, isto é, para o seu reluzir velado. Para Heidegger, só é possível uma filosofia como meditação no outro pensar que se prenuncia na contemporaneidade a caminho de uma revisão da história ocidental como metafísica. E é justamente a meditação que conquista a paciência necessária, e nela, por consequência, a serenidade no relacionamento copertinente entre ente e verdade originária.

\section{Considerações finais}

A abordagem que Heidegger faz a respeito das disposições que levam o ente humano a pensar entra em choque com a história da filosofia ocidental com a qual nos deparamos ao estudarmos as grandes correntes do pensamento. Contudo, essa colisão não é um estímulo para a negação do que a história ontológica nos legou, mas é o chamado ao reconhecimento de que "há" um Nada fundante singelo, que por sua simplicidade, escapa ao poder do ente. Nesse modo de pensar, a fenomenologia de Heidegger se mostra como o caminho para o sentido do seer a partir do seer mesmo. A essência se des-vela ao Da-sein sem que este a encerre em um conceito abarcador. O mistério originário é que se apropria do ente humano e o faz um ser histórico.

Como vimos no decorrer deste trabalho, a humanidade só consegue se deslocar a ponto de ser tornar abertura para a convocação ontológica quando as tonalidades afetivas (Stimmungen) se abrem ao principial. Por isso, a entoação primeira do Da-sein é o pressentimento (Ahnung), que suspeita sobre a existência de um fundamento totalmente outro em relação ao ente, que não pode ser dominado pela técnica. Com pudor (Scheu), o Da-sein pode reter tal fundamento. Retenção (Verhaltenheit) não significa que o seer possa ser calculado e representado, mas que pode ser acolhido com a devida reverência. É por este motivo que Heidegger demonstra o temor (Erschrecken) como a tonalidade afetiva fundamental do outro princípio do pensar que se anuncia, pois indica o 
reconhecimento de que somos apropriados e lançados no mundo pelo abismal do seer. Temor, diferente de medo perante o que nos arrebata, significa deferência à essência da verdade como constrição.

As tonalidades afetivas sobreditas são disposições que levam o ente a meditar no outro princípio do pensamento (onde seer se desvela como nada significante). Nele, o $D a$ sein não representa, não calcula, não domina. Só pode fundar e se fazer no mundo porque antes é arrebatado pela senda da verdade. Se ele pensa é porque algo o levou a pensar. O que o leva a meditar sobre a história é o que o desloca do mundo da factibilidade constante. Já o primeiro princípio (filosofia como metafísica) permanece na dimensão das representações e da vontade de certeza, esquecendo o ser e o seer. Dessa forma, o ser e o seer abandonam o ente.

Ora, se o ente esquece o seer, isso é sinal de ausência de cuidado, mas também é reflexo de sua falta de indigência, isto é, de senso de pobreza e finitude. Esquecer o seer pode significar que o sujeito se acha tão autossuficiente e condição fundamental de si mesmo, que "decai" na ausência de indigência e se pronuncia o senhor da factibilidade produtiva. Mas o senso de finitude, o que Heidegger chama de indigência (Not), só se dá naquele que foi deslocado pelas tonalidades afetivas fundamentais do âmbito das vivências cotidianas, onde imperam o fazer ininterrupto e o discurso inflamado. Todavia, a grande questão é: o humano continuará no esquecimento do seu real fundamento, imerso na atividade técnica mesmo no outro princípio do pensar? Ele aceitará a sua indigência frente ao fundamento nulo ou recusará a sua pobreza existencial e continuará no esquecimento do seer? Como o porvir é sempre um tempo fora do domínio do ente, não sabemos dar as respostas para as questões aqui levantadas. Mas um pensamento é orientador: o ente, querendo ou não, sempre será indigente, uma vez que o seer o deixará por se fazer no mundo. Apenas os raros (com senso de finitude) podem perceber que a verdade nunca está sob o poder da subjetividade. 


\section{Referências bibliográficas}

CASANOVA, Marco Antônio. N. do T., $\mathrm{n}^{\circ}$ 1. In: HEIDEGGER, Martin. As questões fundamentais da filosofia: ( "problemas" seletos da "lógica”). São Paulo: Martins fontes, 2017.

COURTINE, Jean-François. A tragédia e o tempo da história. São Paulo: Editora 34, 2006.

FERNANDES, Marcos Aurélio. O cuidado como amor em Heidegger. In: Revista da Abordagem Gestáltica - XVII (2): jul-dez, 2011.

HEIDEGGER, Martin. Ser e tempo. Petrópolis, RJ: Vozes, 2012.

. Contribuições à filosofia (Do acontecimento apropriador). Rio de Janeiro: Via Verita, 2015.

. Sobre o humanismo. Rio de Janeiro: Tempo Brasileiro, 1967.

INWOOD, Michael. Dicionário Heidegger. Rio de Janeiro: Jorge Zahar, 2002.

MORAES, Eduardo; BIGNOTTO, Newton. Hannah Arendt: diálogos, reflexões, memórias. Belo Horizonte: UFMG, 2001.

RAMOS, Daniel Rodrigues. O Ereignis em Heidegger. Teresópolis: Daimon, 2015.

SÁ, Alexandre Franco de. Heidegger e a essência da universidade. Lusosofia. Disponível em: http://www.lusosofia.net/textos/sa_alexandre_heidegger_universidade.pdf. Acesso em: 10 out. 2018.

Recebido em: 02/02/2019 | Aprovado em: 12/05/2019 